Clinton-Lisell, V., Legerski, E., Rhodes, B., \& Gilpin, S. (accepted). Open Educational Resources as tools to foster equity. In C. Ozaki \& L. Parson (Eds.) Teaching \& learning for social justice and equity in higher education, Volume 2. Palgrave MacMillan. 
Open Educational Resources as Tools to Foster Equity

\author{
Virginia Clinton-Lisell \& Elizabeth Legerski \\ University of North Dakota \\ Bri Rhodes
}

Mount Holyoke College \& University of North Dakota

Staci Gilpin

The College of St. Scholastica \& University of North Dakota

Author Note

Virginia Clinton is an Assistant Professor in Educational Foundations and Research at the University of North Dakota. She may be contacted at (701) 777-5793, virginia.clinton@und.edu, or 231 Centennial Dr., Grand Forks, ND, 58202, USA. 


\begin{abstract}
Open Educational Resources (OER) are teaching and learning materials that are available without access fees and with licensing that affords innovation through OER-enabled pedagogy. In this chapter, we review the financial impact of OER and research evidence that the quality of OER is comparable to that of commercial materials. This is followed by an explanation of how OER licensing allows instructors to revise materials and how OER can be adapted to be more culturally responsive, effectively aligned with learning objectives, and inclusive of student needs. By promoting access to materials, being adaptable to student needs, and providing diverse communities the opportunity to share their voices and knowledge, OER serve as tools to improve teaching and learning and promote social justice in higher education. We present future directions for OER research and implementation as well as sample initiatives to support the adoption of OER and activities that incorporate OER-enabled pedagogy.
\end{abstract}

Keywords: Open Educational Resources; open pedagogy; underserved students 


\section{Key Terms and Definitions}

Open educational resources (OER). "Teaching, learning and research materials in any medium digital or otherwise - that reside in the public domain or have been released under an open license that permits no-cost access, use, adaptation and redistribution by others with no or limited restrictions." (William and Flora Hewlett Foundation, 2019, para. 7).

Open textbooks. OER in textbook form that are typically available without access fees online. These usually can be printed or ordered as bound, hard copies.

Course withdrawal. When students remove themselves from courses after the drop deadline, but before the term is complete.

First-generation college students. Students whose parents or guardians did not attend college or did not complete a college degree (definitions vary by study and institution).

Creative Commons. A nonprofit organization with a mission to promote tools for public sharing of knowledge and culture. Creative Commons licensing provides legal tools and guidelines for rights and restrictions on public use, attribution, and modifications (Creative Commons, 2020). 


\section{Open Educational Resources as Tools to Foster Equity}

Traditionally, educational materials for postsecondary students, such as textbooks, have been developed by commercial publishers. However, the price of these materials has risen substantially over the past few decades (US Bureau of Labor Statistics, 2016). In addition, commercial materials often have restrictive licenses that impede instructors who wish to share, adapt, or remix materials. In response to the issues of high costs and inflexibility due to licensing, there has been a movement to develop and share Open Educational Resources (OER; Butcher, 2015). The term “open educational resources” was first coined by UNESCO (The United Nations Educational, Scientific and Cultural Organization) in 2002, who recognized OER as an important method for ensuring the right to an inclusive and quality education for all (Bliss \& Smith, 2017; Hoosen \& Butcher, 2019). OER are educational materials, such as textbooks, videos, graphics, and syllabi, "that reside in the public domain or have been released under an intellectual property license that permits their free use and re-purposing by others" (William and Flora Hewlett Foundation, 2019, para. 7). As a result, OER do not require paying fees in order to access them (Butcher, 2015) and their licensing allows for the editing and remixing of materials (see Green, 2017, for a thorough explanation of OER licensing).

While those in support of OER often imply such materials help support social justice goals, very few evaluations of OER pedagogies, materials, and outcomes utilize distinctly social justice frameworks. One exception to this is Lambert (2018) who explored the extent to which key OER texts are aligned with the social justice principles of redistributive justice, recognitive justice, and representational justice. The principle of redistributive justice involves allocating resources to support those who have less, while "recognitive justice involves recognition and respect for cultural and gender difference, and representational justice involves equitable 
representation and political voice" (Lambert, 2018, p. 227). We apply this framework to summarize research and scholarship showing how the social justice principles described above can be applied to OER. In doing so, we demonstrate the ability of OER to promote social justice by supporting more equitable access to higher education and by providing opportunities to increase the visibility and voices of marginalized communities and people.

\section{OER Cost-Savings and Educational Access and Success}

The price of commercial materials has negative repercussions on postsecondary students. On average, postsecondary students spend approximately $\$ 1200$ on materials each year (The College Board, 2019). Students are often savvy about avoiding costs, particularly for textbooks, by sharing books with peers, finding pirated versions online, or simply not getting required materials (Jhangiani \& Jhangiani, 2017; Moxley, 2013). According to one estimate, as many as two-thirds of postsecondary students decided not to purchase commercial materials due to the expense (USPIRG, 2014), even though they realize they may suffer academically without these materials (Florida Virtual Campus, 2018). Students often wait until they know for certain that the materials are truly necessary to perform well in a course, with $80 \%$ of students reporting not having the textbook on the first day of class due to the cost (Jenkins et al., 2019). Students also report that they enroll in fewer courses per term because of the financial cost of materials (Florida Virtual Campus, 2018). In addition, the time spent searching for cheaper versions of commercial materials diverts students' time away from academics (Katz, 2019).

Students who are historically underserved in higher education may be particularly affected by textbook costs. A recent survey indicated Latinx students, students who are dependent on financial aid, and first-generation students reported higher levels of stress due to textbook costs than their peers. Latinx and first-generation students also were more likely to 
report that they failed a course because of the high cost of the textbook (Jenkins et al., 2019). In addition, students who identified as both first generation college students and of Black or Latinx background were more likely than their white peers to report that high textbook costs led to lower grades (Nusbaum et al., 2019).

There is clear empirical evidence that OER save students money. In one study comparing the same course taught using an OER textbook in one section and a commercial textbook in another section, students reported spending on average $\$ 80$ less for course materials in the section with an open textbook compared to the section with the commercial textbook (Clinton, 2018). Institutions that have adopted OER initiatives also report substantial aggregate savings for their students. For example, the cost savings calculated as part of one community college's initiative to adopt OER in 11 courses saved students $\$ 34,000$ (Ikahihifo et al., 2017). Students tend to reinvest money saved through OER into their education by enrolling in more courses in a given term, purchasing materials for courses that do not use OER, and for tuition (Ikahihifo et al., 2017).

There is also evidence that OER can save costs by lowering course withdrawal rates, which extend time-to-degree completion (Hall et al., 2003). In fact, one-fifth of students report having withdrawn from a course because of the cost of course materials (Florida Virtual Campus, 2018). Although the long-term costs of withdrawing are likely greater than the immediate costs of accessing required course materials, students may feel compelled to withdraw from courses if they do not have the means to access needed materials. When students withdraw from courses after the drop deadline, they are still responsible for the tuition for that course. The issue of commercial material costs contributing to course withdrawals appears to be particularly problematic for first-generation college students (Nusbaum et al., 2019). 
Evidence suggests that courses using OER materials have substantially lower withdrawal rates. Based on a meta-analysis of 11 studies, the course withdrawal rate was $29 \%$ lower in courses with open textbooks compared to courses with commercial textbooks (Clinton \& Khan, 2019). This overall quantitative effect size is consistent with the qualitative findings of document analyses in which the theme of course material costs being an important factor shaping student withdrawals was identified (Michalski, 2014). In other studies, students have reported that having immediate access to an open textbook without fees enabled them to successfully complete a course rather than withdraw (Hardin et al., 2019). Not requiring expensive course materials may be particularly important for first-generation and low-income students. In fact, according to one study, first-generation college students viewed not requiring expensive materials as a form of faculty support (Ellis et al., 2019).

Given the demonstrated cost savings and impacts on course retention, why haven't more instructors adopted OER materials in their courses? Often one of the primary concerns faculty have about adopting OER is that the quality is inferior to that of commercial materials (Belikov \& Bodily, 2016; Seaman \& Seaman, 2018). This concern is not supported by existing data. In a meta-analysis of 22 studies comparing courses with open textbooks to those with commercial textbooks, it was found that there was no difference in learning performance (Clinton \& Khan, 2019). Furthermore, systematic reviews examining OER more broadly (i.e., beyond textbooks), have also concluded that OER and commercial materials are comparable in terms of learning outcomes (Hilton, 2016, 2019). These systematic reviews also indicate that the overwhelming majority of students and faculty who have actually used OER materials perceive the quality of OER to be as good or better than that of commercial materials (Hilton, 2016, 2019). 
There is evidence that OER may be particularly beneficial in terms of learning outcomes for students who have traditionally been underserved in higher education. In a comparison of the grades of over 20,000 students in courses before and after OER adoption, students overall had higher grades in OER courses than those with commercial textbooks (Colvard et al., 2018). However, the increase was larger for students from lower socioeconomic backgrounds (as indicated by their Pell grant status). This can be explained by the access hypothesis, which would suggest that OER benefit students who would not otherwise have access to necessary learning materials (Grimaldi et al., 2019).

\section{OER Licensing for Recognitive and Representational Justice}

The adoption of OER materials in postsecondary education may also contribute to more equitable learning in other ways beyond reducing financial barriers to student access. OER differ fundamentally from commercial materials and other non-OER materials that may be available online through the use of a Creative Commons copyright (Bissell, 2009). The restrictions on Creative Commons licensing vary, but at its most open level, it allows for permission to engage in what are termed the " $5 \mathrm{R}$ " activities: retain, reuse, revise, remix, and redistribute (Wiley \& Hilton, 2018). Retain activities include having the right to download, store, duplicate, and own personal copies of the OER. Reuse means that an OER created for one purpose could be used for another purpose. The rights to retain and reuse OER allow OER to be available without access fees. Simply having required materials available to each student at the beginning of the semester without cost to students can benefit pedagogy as instructors can plan activities knowing students have their materials (Watson et al., 2017).

Revise activities involve adapting and changing content to meet the needs of the course and/or students. Large-scale changes that are possible with the right to revise include the ability 
to easily translate materials into another language or create an audio version of texts. In this way, options for revising materials facilitate access to course content for diverse populations. Opportunities for revision also allow instructors to remove portions of materials that are irrelevant to course learning objectives. This is a feature students report appreciating about OERenabled pedagogy because they know all of their materials are relevant to the course (DeCarlo, 2019).

Remix activities involve combining material from one source (either in its original or revised form) with material from other sources. For example, an instructor may like most of an introduction to psychology textbook from a particular source but prefer the cognitive psychology unit from another source. Remixing allows this instructor to easily remove the cognitive psychology chapter from one OER source and use one from another OER source in its place. Another example of remixing OER textbooks is adding links to videos or helpful web resources (Mason \& Kimmons, 2018). The rights to revise and remix are key advantages of OER as they afford instructors the ability to adapt materials, which is a good teaching practice (Forbes, 2013; Remillard, 2005).

The rights to revise and remix can also improve inclusion and the diversity of materials. This is critical because content analyses of textbooks across multiple disciplines have indicated a lack of diverse representation in textbooks (Sleeter \& Grant, 1991; Woyshner \& Schocker, 2015). Specifically, studies show that women, people of color, people of lower socioeconomic status, and differently-abled individuals often are underrepresented and/or are represented stereotypically in textbooks (Deckman et al., 2018; Parker et al., 2017; Rosa et al., 2016). While there have been some improvements over time, women, particularly women of color, are still not well represented in many textbooks (Bernabé-Villodre \& Martínez, 2018; Eigenberg \& Park, 
2015; Woyshner \& Schocker, 2015). OER are not inherently immune to issues with diverse representations, but, unlike commercial materials, the licensing of OER allows for editing to improve representation. For example, edits might include changing the names of individuals in examples to allow for a more diverse representation of ethnic identities ${ }^{1}$, removing exclusionary language and adding more inclusive language (e.g., replacing "consumer tribe" in a marketing textbook to "consumer fan club" or changing gendered pronouns to they/them²). Visual representations can also be changed to include a wider range of communities and people by using graphics licensed for reuse (Perez, 2017). Such practices support the social justice goal of facilitating recognition by providing opportunities to increase visibility and share the experiences of marginalized and under-represented populations (Lambert, 2018). Finally, redistribution allows for instructors and students to share their revisions and remixes of OER with others. This can foster networking and collaboration among instructors who may be interested in creating and/or using more inclusive and diverse OER materials (Nascimbeni \& Burgos, 2016; Paskevicius, 2017).

These activities allow for what is termed "OER-enabled pedagogy" (also referred to as open pedagogy or open educational practices), which are teaching practices that are only possible with OER licensing (Wiley \& Hilton, 2018). OER-enabled pedagogy is characterized by collaboration, innovation, creation, and participation of both instructors and students (Karunanayaka et al., 2015). In one study, instructors worked with students to develop graphics and videos that they then shared with others to use in similar courses (using the rights to retain, remix, and redistribute; Wiley et al., 2017). In an American Literature course, students wrote

\footnotetext{
${ }^{1}$ We thank Rajiv Jhangiani for posting this example on Twitter.

${ }^{2}$ We thank Andrea E. Niosi for posting these examples on Twitter
} 
introductions providing contexts to readings in an OER anthology as well as videos and discussion questions, which were then redistributed (DeRosa, 2016). These pedagogical practices would not have been possible with materials regulated by closed copyrights. In an evaluation of such practices, the majority of students reported that OER-enabled pedagogy was as effective, or better, than traditional pedagogy activities (e.g., writing essays and taking quizzes; Hilton et al., 2019). Such practices also have the potential to support representational justice by providing marginalized groups with the opportunity to co-construct texts and tell their stories, rather than having their stories told by others (Lambert, 2018).

\section{OER Initiatives}

Lambert (2018) argues that the affordability, accessibility, and openness components of OER are not sufficient in and of themselves for supporting social justice; rather, working towards social justice using OER requires intentionality and a commitment to address and design for principles of social justice. Institutional support of the implementation of OER and OERenabled pedagogy is critical to realizing the transformative impact of OER (Conole \& Brown, 2018). Proponents of OER have suggested several strategies to help embed open practices into higher education, such as offering institutional incentives to use OER, providing professional development opportunities such as workshops related to OER pedagogy, and providing practical support for the integration of OER materials into courses (Conole \& Brown, 2018). Conole and Brown (2018) also argue that institutional leaders must have knowledge of open pedagogies and be committed to the implementation of OER. In addition, OER must be acknowledged and rewarded in metrics assessing teaching excellence (Conole \& Brown, 2018). For example, some student government associations have awards they present to faculty at their institutions who champion OER. More granular advocacy for the adoption of OER might also include considering 
faculty's use and creation of OER as evidence of excellence in teaching when establishing review, tenure, and promotion criteria.

OER initiatives have been developed across many institutions of higher education in the past two decades (Wesolek et al., 2018). Libraries have been largely on the vanguard of exploring, adopting, and producing OER materials as they are uniquely positioned in institutions to act as both repositories of knowledge as well as a resource to students to make such knowledge more accessible (Kleymeer et al., 2010). Library resources are available to all students, regardless of financial background. Increasingly, university information technology is being housed in campus libraries, uniting technological skills and resource compilation, making them a natural home for open access initiatives (Hess et al., 2016). Although libraries at larger, public institutions have been the most common starting points of OER initiatives (Smith, 2018; Waller et al., 2018; Ross et al., 2018), some smaller institutions and many student groups have also played a key role in the current landscape of college OER initiatives (Miller, 2018;

Batchelor, 2018; Baker \& Ippoliti, 2018). Organizations such as the National Endowment for the Humanities and the Museum and Library Services provide grant funding to support faculty and staff efforts designed to raise awareness of OER, create repositories of open materials, update existing materials, and in some cases generate entirely new materials. Cummings-Sauls and colleagues (2018) compiled examples of significant OER projects and repositories such as the Duke Endowment Libraries, the University of Minnesota's Open Textbook Network, and the University of Massachusetts' ScholarWorks. These networks enable the sharing of institutions' scholarly work with the public to varying degrees in a free and open way.

State system support has proven to be a significant resource for many OER initiatives. For example, the North Carolina State University (NCSU) foundation has funded projects to 
create, remix, and adapt free or significantly reduced cost course materials for their students. The first round of grants distributed $\$ 250,000$ to faculty. The institution estimates the project has saved students around $\$ 300,000$ in textbook costs. The grant also enabled awareness-raising projects such as Open Access Week, to help both students and faculty better understand the costs of academic copyrighting to the institution as well as to the students. This developed into an International Open Access Week in 2016, a documentary miniseries called the "Power of Open", and a North Carolina student leader conference, OpenCon (Rigling \& Cross, 2018).

In addition to initiatives to encourage and train faculty to use and develop OER, there are also initiatives to improve the accessibility of OER. Although open textbooks are typically designed to be accessible for people with disabilities (Baker et al., 2009), many interactive digital resources, both OER and commercial, have been justifiably criticized for lack of accessibility for people with disabilities (Hashey \& Stahl, 2014). In response, there have been several initiatives launched to evaluate or improve the accessibility of OER websites and interactive materials (Moreno et al., 2018). For example, the OERfAll website is designed to be personalized to users' unique needs and offers accessibility features to meet those needs (Navarette \& Luján-Mora, 2018). Another example includes the Open Course Ware initiative, which organizes a variety of OER for use in specific courses, and has developed a process for reviewing the accessibility of its resources and providing feedback to instructors so their accessibility can be improved (Rodrígez et al., 2017).

\section{Future Directions for Social Justice and OER}

OER has been hailed as a tool for creating a more just and equitable educational environment (Hartnett, 2017; Huitt, \& Monetti, 2017). However, the measures chosen to assess OER and equity matter. Historically, measures such as test score gaps or grades between 
different populations have been used as evidence of educational equality (or inequality) (Polat, 2011; Baraniuk et al., 2017). The underlying assumption is that high test scores and grades represent high education quality, while lower test scores and grades indicate lower education quality. Nevertheless, such generalizations can be problematic. While test scores and grades matter, they are often symptomatic of deeper inequalities - inequalities requiring agile, adaptable, and non-essentialized resources - rather than an accurate measure of knowledge and skill (Lambert, 2018; Landorf \& Nevin, 2007). Without using measures such as test scores and grades as a proxy for education quality, there is a need to redefine success measures in regards to education materials. This need dovetails nicely with many OER goals, mainly by addressing areas of concern that are caused primarily by economic inequality. For example, making assessments less driven by numbers and more about skills would help to reduce the gap between students who can afford test preparation programs and those who cannot (McKenzie et al., 2008). OER can support these by making skill-based resources more accessible. However, a deeper understanding of justice, and the ways in which OER may inadvertently replicate injustice, are critical for educators seeking to use OER to support more just learning environments.

Drawing on work by Fraser (1995), Lambert defined social justice in a way that is salient to OER. Lambert (2018) conceptualized social justice generally as, "a process and also a goal to achieve a fairer society which involves actions guided by the principles of redistributive justice, recognitive justice or representational justice (pg. 227)." Often the argument for OER simply stops at "openness is good." This simplistic idea stops short of examining specifically who OER is good for. "Good" may not necessarily support the goal of redistributive, recognitive, and representational justice. For example, if "good" means "good for everyone equally," then such 
outcomes may further prop up existing inequalities. In this way, focusing exclusively on redistributive justice, may benefit privileged students in the same way as marginalized students, leaving a gap between these groups that remains difficult to bridge (Lambert, 2018).

Defining social justice in open education therefore should focus on assessing freedoms and capabilities that result from these initiatives (Sullivan, 2011). In consideration of these factors, Lambert (2018) came to define a more justice-oriented approach to open education: "the development of free digitally-enabled learning materials and experiences primarily by and for the benefit and empowerment of non-privileged learners who may be under-represented in education systems or marginalized in their global context (pg. 239)." Understanding how just programs should look is an essential step in infusing justice alignment throughout the curriculum. Given the difficulties many educators and students in the US and around the world face in accessing technology and developing technological skills, OER initiatives should not be measured by technical sophistication, but rather how they support Fraser's three features of social justice (i.e., redistributive, recognitive, and representational).

In considering representational and recognitive justice, Polat (2011) notes that many initiatives have stated goals of promoting greater inclusion, but often mistake integration for inclusion. Inclusion requires a level of intentionality that not only invites diverse stakeholders to the table, but gives them equal voices in decision-making. In a field where decision-makers are often people of privilege, educators cannot lose sight of their own positionality in considering ways to remove bias and essentialism when considering universal material design (Hackman, 2008).

\section{Conclusion}


OER afford greater student access to education through removing financial barriers.

Furthermore, the licensing of OER enables instructors to promote redistributive, recognitive, and representational justice in their courses in manners not feasible with traditional copyrights (Lambert, 2018). There have been a variety of initiatives to promote, develop, and share OER at the institutions that were reviewed in this chapter. However, it should be noted that OER is a developing movement that must consider the needs of diverse learners in order to truly contribute to social justice causes.

\section{Appendix}

\section{Student Course Project Incorporating OER-enabled Pedagogy}

\section{Context}

It can be difficult for instructors working in teacher preparation programs to locate OER textbooks and other resources that address broad foundational elements along with issues, legislation, and practices applicable at the local/state level. The IRIS Center supported by the U.S. Department of Education's Office of Special Education Programs and located at Vanderbilt University's Peabody College offers free online interactive resources, which are licensed by Creative Commons that "translate research about the education of students with disabilities into practice" (Vanderbilt University, 2020). Included in their comprehensive coverage of evidencebased topics are behavior and learning strategies along with data collections and analysis. However, IRIS Center resources do not address the implementation of practices and teacher licensure standards relevant to specific states. Thus, IRIS Center resources are ripe for OERenabled pedagogy through revision/remixing.

To that end, in an Introduction to Special Education course, the instructor used IRIS Center resources as their primary course text/resource. To add the local/state context, they 
assigned students to create resource guides that went with each course topic using other OERs of their choosing. The student-produced resource guides were created in Google Sites (free of charge) and expanded upon IRIS Center resources by sharing local/state interpretations of legislation, supports, best practices, and examples. The resource guides contained interactive features such as hyperlinks to other websites, podcasts, and videos. Students were also encouraged to create and embed podcasts and videos. Throughout the term, the instructor scaffolded students by providing them with periodic feedback, suggestions for resources, and by creating time for them to workshop their resource guides with one another. At the end of the semester, student volunteers put together a "best of the best" Google Site that highlighted the student-created resources that students found to be most helpful. This Google Site then served as the foundation for future courses as the resource guide and the website continued to be reviewed and revised.

\section{Instructions to students}

Imagine that you are a parent/guardian, and your child is struggling in school. You are trying to navigate getting help for your child. The first thing many of us would do is open up a browser and start researching. Your task for this series of assignments is to take what you are learning in this course and channel it into something useful and practical - the creation of a webbased resource guide intended to inform parents about the why, what, and how of getting their child support, regardless of whether they have a disability or not, because if a student is struggling, this is a sign they need something.

Your resource guide will explain the special education process, working with students with disabilities, those that are gifted and talented and English language learners along with Section 504, the Individuals with Disabilities Education Act (IDEA), and other legislation that 
supports the success of all learners. In the spirit of Universal Design for Learning (UDL), you may include elements in your resource guides that are typed, video, and/or audio. The resource guides will be created in a Google Site (web site) that you will create free of charge using your student Google Account.

The goal is for you to leave this course with a resource guide that you can use in your future work. A secondary goal is to use the information you include in your resource guides to create a course Google Site that highlights the student-created resources that you found to be most helpful. This Google Site will then serve as the foundation for future courses as the resource guide project continues, and the website will be continuously reviewed and revised. Your instructor will need student volunteers to assist with the creation/updating of the course Google Site. Please let me know if you are interested. Course extra credit will be provided for anyone who volunteers.

Before you get started, it is imperative that you understand your audience as you are creating the content for your resource guide. Avoid educational jargon as much as possible while still maintaining a professional tone and including appropriate academic language. To that end, I would encourage you to do some research on your own and see what others in your state/region are putting on their district websites. In addition, review the respective state agency websites related to supporting students with disabilities. You might ask teachers you know and others who work in schools for feedback and/or ideas. You may direct your site at either elementary, middle school, or high school students and their parents/guardians. PLEASE be creative - the more professional, yet engaging, a site is, the more comforted a parent/guardian will feel! 


\section{Suggestions for Future Reading}

\section{Systematic Reviews and Meta-Analyses on OER}

Clinton, V., \& Khan, S. (2019). Efficacy of open textbook adoption on learning performance and course withdrawal rates: A meta-analysis. AERA Open, 5(3), 1-20.

https://doi.org/10.1177\%2F2332858419872212

Hilton, J. (2016). Open educational resources and college textbook choices: A review of research on efficacy and perceptions. Educational Technology Research and Development, 64(4), 573-590. https://doi.org/10.1007/s11423-016-9434-9

Hilton, J. (2019). Open educational resources, student efficacy, and user perceptions: a synthesis of research published between 2015-2018. Educational Technology Research and development. https://doi.org/10.1007/s11423-019-09700-4

\section{Overviews of OER and OER-Enabled Pedagogy}

Jhangiani, R. S., \& Jhangiani, S. (2017). Investigating the perceptions, use, and impact of open textbooks: A survey of post-secondary students in British Columbia. The International Review of Research in Open and Distributed Learning, 18(4).

https://doi.org/10.19173/irrodl.v18i4.3012

Wiley, D. \& Hilton, JL, III. 2018. Defining OER-Enabled Pedagogy. The International Review of Research in Open and Distributed Learning, 19(4). https://doi.org/10.19173/irrodl.v19i4.3601

\section{Websites with OER Collections or Other Resources}

Minnesota Open Textbook Library (collection of open textbooks with faculty reviews):

https://open.umn.edu/opentextbooks/ 
OER Commons (online library of OER and network of educators to collaborate on open pedagogy): https://www.oercommons.org/ Open Course Ware (collection of freely-available content from Massachusetts Institute of Technology courses): https://ocw.mit.edu/index.htm

Open Education Group (website about an interdisciplinary research group focused on OER empirical research and sharing open pedagogy resources): http://openedgroup.org/ 


\section{References}

Artiles, A. J., Harris-Murri, N., \& Rostenberg, D. (2006). Inclusion as Social Justice: Critical Notes on Discourses, Assumptions, and the Road Ahead. Theory Into Practice, 45(3), 260-268. https://doi.org/10.1207/s15430421tip4503_8

Baker, A., \& Ippoliti, C. (2018). Student-Driven OER: Championing the Student Voice in Campus-Wide Efforts. In A. Wesolek, J. Lashley, \& A. Langley (Eds.) OER: A Field Guide for Academic Librarians (pp. 239-252). Pacific University Press.

Baker, J., Thierstein, J., Fletcher, K., Kaur, M., \& Emmons, J. (2009). Open Textbook Proof-ofConcept via Connexions. The International Review of Research in Open and Distributed Learning, 10(5). https://doi.org/10.19173/irrodl.v10i5.633

Baraniuk, R., Finkbeiner, N., Harris, D., Nicholson, D., \& Williamson, D. (2017). Free is Not Enough. In R. S. Jhangiani \& R. Biswas-Diener (Eds.), Open (pp. 219-226). Ubiquity Press; JSTOR. https://www.jstor.org/stable/j.ctv3t5qh3.21

Batchelor, C. (2018). Transforming Publishing with a Little Help From Our Friends: Supporting an Open Textbook Pilot Project with Friends of the Libraries Grant Funding. In OER: $A$ Field Guide for Academic Librarians (pp. 415-432). Pacific University Press.

Belikov, O. M., \& Bodily, R. (2016). Incentives and barriers to OER adoption: A qualitative analysis of faculty perceptions. Open Praxis, 8(3), 235-246. https://doi.org/ 10.5944/openpraxis.8.3.308

Bernabé-Villodre, M. D. M., \& Martínez-Bello, V. E. (2018). Analysis of gender, age and disability representation in music education textbooks: A research update. International Journal of Music Education, 36(4), 494-508.

https://doi.org/10.1177\%2F0255761418763900 
Bissell, A. N. (2009). Permission granted: Open licensing for educational resources. Open Learning: The Journal of Open, Distance and e-Learning, 24(1), 97-106. https://doi.org/10.1080/02680510802627886

Bliss, T.J. \& Smith, M. (2017). A Brief History of Open Educational Resources. In: R.S. Jhangiani and R. Biswas-Diener (Eds.) Open: The Philosophy and Practices that are Revolutionizing Education and Science. (pp. 9-27). London: Ubiquity Press.

Butcher, N. (2015). A basic guide to open educational resources (OER). British Columbia, Canada: Commonwealth of Learning, Vancouver and UNESCO. http://oasis.col.org/handle/11599/36

Clinton, V., \& Khan, S. (2019). Efficacy of open textbook adoption on learning performance and course withdrawal rates: A meta-analysis. AERA Open, 5(3), 1-20. https://doi.org/10.1177\%2F2332858419872212

Clinton, V. (2018). Savings without sacrifices: A case study of open-source textbook adoption. Open Learning: The Journal of Distance and Open Learning 33(3), 177-189. https://doi.org/10.1080/02680513.2018.1486184

Colvard, N. B., Watson, C. E., \& Park, H. (2018). The impact of Open Educational Resources on various student success metrics. International Journal of Teaching and Learning in Higher Education, 30(2), 262-276. http://www.isetl.org/ijtlhe/pdf/IJTLHE3386.pdf

Conole, G., \& Brown, M. (2018). Reflecting on the Impact of the Open Education Movement. Journal of Learning for Development, 5(3), 187-203. https://j14d.org/index.php/ej14d/article/view/314

Creative Commons (2020). What is Creative Commons? Retrieved from https://creativecommons.org/faq/\#what-is-creative-commons-and-what-do-you-do 
Cummings-Sauls, R., Ruen, M., Beaubien, S., \& Smith, J. (2018). Open Partnerships: Identifying and Recruiting Allies for Open Educational Resources Initiatives. OER: A Field Guide for Academic Librarians. 72. Retrieved from https://scholarworks.umass.edu/librarian_pubs/72

DeCarlo, M. P. (2019, November 7). Teaching note: Creating open textbooks for social work education. https://doi.org/10.31235/osf.io/qf3t5

Deckman, S. L., Fulmer, E. F., Kirby, K., Hoover, K., \& Mackall, A. S. (2018). Numbers are just not enough: a critical analysis of race, gender, and sexuality in elementary and middle school health textbooks. Educational Studies, 54(3), 285-302.

https://doi.org/10.1080/00131946.2017.1411261

DeRosa, R. (2016). My open textbook: Pedagogy and practice. https://robinderosa.net/uncategorized/my-open-textbook-pedagogy-and-practic

Eigenberg, H. M., \& Park, M.S. (2016). Marginalization and invisibility of women of color: A Content analysis of race and gender images in introductory criminal Justice and criminology texts. Race and Justice, 6(3), 257-279. https://doi.org/10.1177\%2F2153368715600223

Ellis, J. M., Powell, C. S., Demetriou, C. P., Huerta-Bapat, C., \& Panter, A. T. (2019). Examining first-generation college student lived experiences with microaggressions and microaffirmations at a predominately White public research university. Cultural Diversity and Ethnic Minority Psychology, 25(2), 266-279. https://doi.org/10.1037/cdp0000198

Florida Virtual Campus. (2018). 2018 Florida Student Textbook Survey. Tallahassee, FL: Author. 
Fraser, F. (1995). From Redistribution to Recognition? Dilemmas of Justice in a "Post-Socialist" Age. New Left Review, 1(212). https://newleftreview.org/I/212/nancy-fraser-fromredistribution-to-recognition-dilemmas-of-justice-in-a-post-socialist-age

Forbes, C. T. (2013). Curriculum-dependent and curriculum-independent factors in preservice elementary teachers' adaptation of science curriculum materials for inquiry-based science. Journal of Science Teacher Education, 24(1), 179-197. https://doi.org/10.1007/s10972-011-9245-0

Green, C. 2017. Open Licensing and Open Education Licensing Policy. In: Jhangiani, R S and Biswas-Diener, R. (eds.) Open: The Philosophy and Practices that are Revolutionizing Education and Science. 29-41.

Grimaldi, P., Basu Mallick, D., Waters, A.E., \& Baraniuk, R.G. (2019). Do open educational resources improve student learning? Implications of the access hypothesis. PLoS ONE 14(3): e0212508. http://doi.org/10.1371/journal.pone.0212508

Hackman, H. (2008). Broadening the Pathway to Academic Success: The Critical Intersections of Social Justice Education, Critical Multicultural Education, and Universal Instructional Design. In Pedagogy and Student Services for Institutional Transformation: Implementing Universal Design in Higher Education. University of Minnesota.

Hall, M., Smith, K., Boeckman, D., Ramachandran, V., \& Jasin, J. (2003, October). Why do students withdraw from courses? Southern Association for Institutional Research, 01-11. San Antonio, TX.

Hardin, E.E., Eschman, B., Spengler, E.S., Grizzell, J.A., Moody, A.T., Ross-Sheehy, S., \& Fry, K.M. (2019). What happens when trained graduate student instructors switch to an open 
textbook? A controlled study of the impact on student learning outcomes. Psychology Learning \& Teaching, https://doi.org/10.1177/1475725718810909

Hartnett, J. (2017). DIY Open Pedagogy: Freely Sharing Teaching Resources in Psychology. In R. S. Jhangiani \& R. Biswas-Diener (Eds.), Open (pp. 245-254). Ubiquity Press; JSTOR. https://www.jstor.org/stable/j.ctv3t5qh3.24

Hashey, A. I., \& Stahl, S. (2014). Making online learning accessible for students with disabilities. Teaching exceptional children, 46(5), 70-78.

Hess, J., Nann, A. J., \& Riddle, K. E. (2016). Navigating OER: The Library's Role in Bringing OER to Campus. The Serials Librarian, 70(1-4), 128-134.

https://doi.org/10.1080/0361526X.2016.1153326

Hilton, J. (2016). Open educational resources and college textbook choices: A review of research on efficacy and perceptions. Educational Technology Research and Development, 64(4), 573-590. https://doi.org/10.1007/s11423-016-9434-9

Hilton, J. (2019). Open educational resources, student efficacy, and user perceptions: a synthesis of research published between 2015-2018. Educational Technology Research and development. https://doi.org/10.1007/s11423-019-09700-4

Hilton, J., Wiley, D., Chaffee, R., Darrow, J., Guilmett, J., Harper, S., \& Hilton, B. (2019). Student perceptions of open pedagogy: An exploratory study. Open Praxis, 11(3), 275.

Hoosen, S., \& Butcher, N. (2019). Understanding the Impact of OER: Achievements and Challenges. https://iite.unesco.org/wpcontent/uploads/2019/04/Understanding_the_impact_of_OER_2019_final.pdf 
Huitt, W. G., \& Monetti, D. M. (2017). Openness and the Transformation of Education and Schooling. In R. S. Jhangiani \& R. Biswas-Diener (Eds.), Open (pp. 43-66). Ubiquity Press; JSTOR. https://www.jstor.org/stable/j.ctv3t5qh3.8

Ikahihifo, T. K., Spring, K. J., Rosecrans, J., \& Watson, J. (2017). Assessing the savings from open educational resources on student academic goals. International Review of Research in Open and Distributed Learning, 18(7). https://doi.org/10.19173/irrodl.v18i7.2754

Jenkins, J. J., Hannans, J., Sanchez, L., \& Leafstedt, J. (n.d.). White paper: Textbook affordability and student success for historically underserved populations at CSUCI. https://www.csuci.edu/tli/openci/

Jhangiani, R. S., \& Jhangiani, S. (2017). Investigating the perceptions, use, and impact of open textbooks: A survey of post-secondary students in British Columbia. The International Review of Research in Open and Distributed Learning, 18(4). https://doi.org/10.19173/irrodl.v18i4.3012

Karunanayaka, S., Naidu, S., Rajendra, J. C. N., \& Ratnayake, H. U. W. (2015). From OER to OEP: Shifting practitioner perspectives and practices with innovative learning experience design. Open Praxis, 7(4), 339-350. https://www.learntechlib.org/p/161991/

Katz, S., (2019). Student textbook purchasing: the hidden cost of time. CUNY Academic Works. https://academicworks.cuny.edu/le_pubs/251

Kleymeer, P., Kleinman, M., \& Hanss, T. (2010). Reaching the Heart of the University: Libraries and the Future of OER (Open ED 2010 Proceedings). UOC, OU, BYU. https://hdl.handle.net/10609/4866 
Lambert, S. R. (2018). Changing our (Dis)Course: A Distinctive Social Justice Aligned Definition of Open Education. Journal of Learning for Development, 5(3), 225-244. https://orcid.org/0000-0003-2722-9684

Landorf, H., \& Nevin, A. (2007). Inclusive global education: Implications for social justice. Journal of Educational Administration, 45(6), 711 https://doi.org/10.1108/09578230710829892

Mason, S. L., \& Kimmons, R. (2018). Effects of Open Textbook Adoption on Teachers' Open Practices. International Review of Research in Open and Distributed Learning, 19(3). https://doi.org/10.19173/irrodl.v19i3.3517

McKenzie, K. B., Christman, D. E., Hernandez, F., Fierro, E., Capper, C. A., Dantley, M., González, M. L., Cambron-McCabe, N., \& Scheurich, J. J. (2008). From the Field: A Proposal for Educating Leaders for Social Justice. Educational Administration Quarterly, 44(1), 111-138. https://doi.org/10.1177/0013161X07309470

Michalski, G.V. (2014). In their own words: A text analytics investigation of college course attrition. Community College Journal of Research and Practice, 38(9), 811-826. https://doi.org/10.1080/10668926.2012.720865

Miller, J. (2018). Bringing OER to the Liberal Arts: An Innovative Grant Program. In OER: $A$ Field Guide for Academic Librarians (pp. 399-413). Pacific University Press.

Moreno, N., Caro, E.T., \& Cabedo, R. (2018) "Systematic Review: OER and Disability," 2018 IEEE 5th International Congress on Information Science and Technology (CiSt), Marrakech, (pp. 428-431. https://doi.org/10.1109/CIST.2018.8596659

Moxley, J. (2013). Open textbook publishing. Academe, 99(5), 40. https://www.aaup.org/article/open-textbook-publishing\#.WNPuNRLyvq0 
Nascimbeni, F., \& Burgos, D. (2016). In search for the Open Educator: Proposal of a definition and a framework to increase openness adoption among university educators. International Review of Research in Open and Distributed Learning, 17(6), 1-17. https://doi.org/10.19173/irrodl.v17i6.2736

Navarrete, R., \& Luján-Mora, S. (2018). Bridging the accessibility gap in Open Educational Resources. Universal Access in the Information Society, 17(4), 755-774. https://doi.org/10.1007/s10209-017-0529-9

Nusbaum, A. T., Cuttler, C., \& Swindell, S. (2019). Open Educational Resources as a Tool for Educational Equity: Evidence from an Introductory Psychology Class. Frontiers in Education, 14, 152-200.

Parker, R., Larkin, T., \& Cockburn, J. (2017). A visual analysis of gender bias in contemporary anatomy textbooks. Social Science \& Medicine, 180, 106-113. https://doi.org/10.1016/j.socscimed.2017.03.032

Paskevicius, M. (2017). Conceptualizing open educational practices through the lens of constructive alignment. Open Praxis, 9(2), 125-140. https://www.learntechlib.org/p/181424/

Perez, J. E. (2017). Images and the Open Educational Resources (OER) movement. The Reference Librarian, 58(4), 229-237. https://doi.org/10.1080/02763877.2017.1346495

Polat, F. (2011). Inclusion in education: A step towards social justice. International Journal of Educational Development, 31(1), 50-58. https://doi.org/10.1016/j.ijedudev.2010.06.009 Remillard, J. T. (2005). Examining key concepts in research on teachers' use of mathematics curricula. Review of Educational Research, 75(2), 211-246. https://doi.org/10.3102\%2F00346543075002211 
Rigling, L. \& Cross, W. (2018). Getting to know you: How we turned community knowledge into open advocacy. In A. Wesolek, J. Lashley, \& A. Langley (Eds.) OER: A Field Guide for Academic Librarians (pp. 351-380). Pacific University Press.

Rodríguez, G., Pérez, J., Cueva, S., \& Torres, R. (2017). A framework for improving web accessibility and usability of Open Course Ware sites. Computers \& Education, 109, 197215. https://doi.org/10.1016/j.compedu.2017.02.013

Rosa, N. M., Bogart, K. R., Bonnett, A. K., Estill, M. C., \& Colton, C. E. (2016). Teaching about disability in psychology: An analysis of disability curricula in US undergraduate psychology programs. Teaching of Psychology, 43(1), 59-62. https://doi.org/10.1177\%2F0098628315620885

Ross, H., Lucky, S., \& Francis, D. (2018). A Grassroots Approach to OER Adoption: The University of Saskatchewan Experience. In OER: A Field Guide for Academic Librarians (pp. 381-398). Pacific University Press.

Seaman, J. E. \& Seaman, J. (2017). Opening the textbook: Educational resources in U.S. higher education, 2017. https://www.onlinelearningsurvey.com/oer.html

Sleeter, C. E., \& Grant, C. A. (1991). Race, class, gender, and disability in current textbooks. In M. W. Apple \& L. K. Christian-Smith (Eds.), The politics of the textbook (pp. 78-110 ). New York, NY: Routledge.

Smith, J. (2018). Seeking Alternatives to High-Cost Textbooks: Six Years of The Open Education Initiative at the University of Massachusetts Amherst. In OER: A Field Guide for Academic Librarians (pp. 333-350). Pacific University Press. 
Sullivan, J. (2011). Free, Open Source Software Advocacy as a Social Justice Movement: The Expansion of F/OSS Movement Discourse in the 21st Century. Journal of Information Technology \& Politics, 8(3), 223-239. https://doi.org/10.1080/19331681.2011.592080

The College Board (2019). Trends in Higher Education Series: Trends in College Pricing, 2018. https://research.collegeboard.org/pdf/trends-college-pricing-2018-full-report.pdf

U.S. Public Interest Research Group Education Fund and Student Public Interest Research Groups.(USPIRG) (2014). Fixing the Broken Textbook Market. Washington, DC. http://www.uspirg.org/reports/usp/fixing-brokentextbook-market

Vanderbilt University. (2020). IRIS Center. https://iris.peabody.vanderbilt.edu/

Waller, J., Taylor, C., \& Zemke, S. (2018). From Start-Up to Adolescence: University of Oklahoma's OER Efforts. In A. Wesolek, J. Lashley, \& A. Langley (Eds.) OER: A Field Guide for Academic Librarians (pp. 351-380). Pacific University Press.

Watson, C. E., Domizi, D. P., \& Clouser, S. A. (2017). Student and Faculty Perceptions of OpenStax in High Enrollment Courses. The International Review of Research in Open and Distributed Learning, 18(5). https://doi.org/10.19173/irrodl.v18i5.2462

Wesolek, A., Lashley, J., \& Langley, A. (2018). OER: A Field Guide for Academic Librarians. Pacific University Press.

Wiley, D. \& Hilton, JL, III. 2018. Defining OER-Enabled Pedagogy. The International Review of Research in Open and Distributed Learning, 19(4). https://doi.org/10.19173/irrodl.v19i4.3601

Wiley, D., Webb, A., Weston, S., \& Tonks, D. (2017). A preliminary exploration of the relationships between student created OER, sustainability, and student success. The 
International Review of Research in Open and Distributed Learning, 18(4).

https://doi.org/10.19173/irrodl.v18i4.3022

William \& Flora Hewlett Foundation (2019). Open Educational Resources.

https://hewlett.org/strategy/open-educational-resources/

Woyshner, C., \& Schocker, J. B. (2015). Cultural parallax and content analysis: Images of Black women in high school history textbooks. Theory \& Research in Social Education, 43(4), 441-468. https://doi.org/10.1080/00933104.2015.1099487 